\title{
Orak Hücre Anemili Hastalarda Osteoporoz İlişkili Biyokimyasal Markerlerin Tanıdaki Yeri
}

\author{
(iD) Meryem Korkmaz ${ }^{1}$, (iD) Berna Kuş ${ }^{2}$, (DD Emre Dirican³ ${ }^{3}$ (iD) Abdullah Arpacı ${ }^{4}$ \\ ${ }^{1}$ MSc. Öğr. Hatay Mustafa Kemal Üniversitesi, Tıp Fakültesi, Tıbbi Biyokimya Anabilim Dalı, Hatay, Türkiye. \\ ${ }^{2}$ PhD. Öğr. Hatay Mustafa Kemal Üniversitesi Tıp Fakültesi, Moleküler Biyokimya ve Genetik Anabilim Dalı, Hatay, Türkiye. \\ ${ }^{3}$ Dr. Öğr. Üyesi, Hatay Mustafa Kemal Üniversitesi, Tıp Fakültesi, Biyoistatistik Anabilim Dalı, Hatay, Türkiye. \\ ${ }^{4}$ Prof. Dr. Hatay Mustafa Kemal Üniversitesi Tıp Fakültesi, Tıbbi Biyokimya Anabilim Dalı, Hatay, Türkiye.
}

$\ddot{0} z$

Orak Hücre Anemili Hastalarda Osteoporoz ilișkili Biyokimyasal Markerlerin Tanıdaki Yeri

Amaç: Orak hücreli anemi (OHA)'de osteopeni ve osteoporoz riski net olarak ortaya konmamıștır. Bu çalıșmada OHA-osteoporoz ilișkisini araştırmak amacıyla kemik yapım/yıkım belirteçleri bir arada değerlendirilerek aralarındaki korelasyonun incelenmesi amaçlandı.

Gereç ve Yöntem: Çalıșmanın hasta grubu 33 orak hücreli birey ve kontrol grubu ise 34 sağlıklı bireyden olușturuldu. Kemik yapım belirteçlerinden Tip 1 kollajen N-terminal propeptit (P1NP), Tip 1 kollajen C-terminal propeptit (P1CP), Kemik Alkalen Fosfataz (BALP) ve Osteokalsin (OC), kemik yıkım belirteçlerinden ise, Tip 1 kollajen karboksiterminal bağı telopeptit (CTX), Pridinolin (PYD) ve Deoksipridinolin (DPD) ve Hidroksiprolin (HYP) analiz edildi. Ayrıca grupların 25(OH)D düzeyleri ölçüldü.

Bulgular: OC düzeyi hasta grubunda kontrol grubuna kıyasla anlamlı derecede yüksekti. $(p=0.016)$. 25(OH)D düzeyi hasta grubunda kontrol grubuna kıyasla önemli ölçüde düşüktü. ( $p=0.01$ ). Gruplar arasında diğer yapım ve yıkım belirteçlerinde (PINP, PICP, PYD, DPD, BALP, (TX, HYP) istatistiksel olarak anlamlı fark bulunmadı.

Sonuç: OHA'nın kemik metabolizmasına etkisinin anlașılmasında kemik döngüsü belirteçlerinin de değerlendirilmesinin tanıya daha fazla katkıda bulunacağı öngörülmüștür.

Anahtar Kelimeler: Orak Hücre, Osteopeni, Osteoporoz, Kemik Döngüsü Belirteçleri

\section{Abstract}

\section{The Role of Biochemical Markers Associated with Osteoporosis in Patients with Sickle Cell Anemia in Diagnosis}

objective: The risk of osteopenia and osteoporosis has not been clearly defined in sickle cell anemia (SCA). In this study, it was aimed to evaluate the bone formation/resorption markers together and examine the relationships between each other in order to investigate the relationship between SCA and osteoporosis.

Methods: Our study included 33 patients with sickle cell anemia and 34 healthy controls. Bone formation markers are Type 1 collagen $\mathrm{N}$-terminal propeptide (P1NP), Type 1 collagen C-terminal propeptide (P1CP), Bone Alkaline Phosphatase (BALP) and Osteocalcin (OC), and bone resorption markers are Type 1 collagen carboxyterminal telopeptide (CTX), Pyridinoline (PYD) and Deoxypyridinoline (DPD) and Hydroxyproline (HYP) were analyzed. In addition, 25(OH)D levels of the groups were assayed.

Results: The OC level was significantly higher in the patient group compared to the control group $(p=0.016)$. 25(OH)D level was significantly decreased in the patient group compared to the control group $(p=0.01)$. There was no statistically significant difference between the groups for both bone formation and resorption markers (PINP, PICP, PYD, DPD, BALP, CTX, HYP).

Conclusion:It is predicted that the evaluation of bone turnover markers will contribute more to the diagnosis in understanding the effect of SCA on bone metabolism.

Keywords: Sickle Cell Anemia, Osteopenia, Osteoporosis, Bone Turnover Markers

Nasıl Atıf Yapmalı: Korkmaz M, Kuș B, Dirican E, Arpacı A. Orak Hücre Anemili Hastalarda Osteoporoz illișkili Biyokimyasal Markerlerin Tanıdaki Yeri. MKÜ Tıp Dergisi. 2021;12(44):231-235. https://doi.org/10.17944/mkutfd.979179

Sorumlu Yazar/Corresponding Author: Prof. Dr. Abdullah Arpacı

Geliș/Received: 5 Ağustos 2021

Email: arpaci57@gmail.com

Kabul/Accepted: 25 Ekim 2021

ORCID iD: 0000-0002-6077-8258 


\section{Giris}

Hemoglobinopatiler, yaygın görülen kalıtsal kan hastalıkları olarak sadece ülkemizde değil dünyada da önemli bir halk sağ lığı sorunudur (1).

OHA'da anormal globin sentezi sonucunda mutant bir hemoglobin olan Hemoglobin S (HbS) meydana gelir. HbS; beta globin zincirindeki asidik ve hidrofilik bir aminoasit olan glutamik asit yerine hidrofobik bir aminoasit olan valin ( $\beta 6 \mathrm{Glu} \rightarrow$ Val) aminoasidinin geçmesiyle oluşur $(1,2)$. Negatif yüklü glutamik asidin kaybı ile elektroforetik mobilitede değișiklikler oluşur ve globin zincirlerinin oksijensiz ortamda polimerleșmeye eğilimi gelișir. Oraklașarak esnek yapılarını kaybeden eritrositler küçük damarlarda tıkanıklığa sebep olurlar $(3,4)$.

Orak hücre hemoglobine bağlı bir kan hastalığı olduğundan direk oksijen metabolizmasını bozmakta ve bunun sonucu olarak hayat kalitesini azaltan negatif etkilere neden olmaktadır. Doğrudan günlük yaşamı sınırlandırarak yașam kalitesini düșüren bu hastalığın bir sonucu olarak, orak hücre anemili hastalarda osteoporoz riskinin arttığına dair çeliş̧ili verilere literatürde rastlanmaktadır. Osteoporoz, kemiklerin hassasiyetinin artmasına ve kırılmaya karșı gösterilen direncin azalmasına yol açmaktadır $(5,6)$. Bu konuda çeşitli çaIsșmalar yapılmış fakat orak hücreli anemide osteopeni ve osteoporoz ile karșılașma intimali henüz tam olarak ortaya konmamıștır. OHA'da kronik hemolitik anemi kemik iliği hiperplazisine yol açar. Böylelikle kemik iliği boșluklarının kırmızı ilikle dolmasına neden olarak kemik trabekülasyonunda ve korteksinde incelme, düzensizleșmelere neden olmaktadır (7). Çalışmamızda; kemik yapım belirteçlerinden Tip 1 kollajen N-terminal propeptit (P1NP), Tip 1 kollajen C-terminal propeptit (P1CP), Kemik Alkalen Fosfataz (BALP ) ve Osteokalsin (OC), kemik yıkım belirteçlerinden ise, Tip 1 kollajen karboksiterminal bağlı telopeptit (CTX), Pridinolin (PYD) ve Deoksipridinolin (DPD) ve Hidroksiprolin (HYP) tercih edilmiștir. Literatürde PINP ve HYP belirteçlerinin orak hücrede çalıșıldığı herhangi bir kaynağa rastlanmamıștır. Orak hücre anemililerde 25(OH)D sıklıkla kanda $20 \mathrm{ng} / \mathrm{mL}$ 'den düşük konsantrasyonlarda gözlenmektedir (8). Birçok çalıșmada orak hücreli anemi hastalarında vitamin D eksikliği ve kemik hastalıkları ile ilișkili bulunmuștur (9). Bu nedenle çalıșmamızda ayrıca 25(OH)D spektrofotometrik olarak ölçülmüștür.

Bu bilgiler ıșığında çalışmamızda orak hücre anemisi-osteoporoz ilișkisini incelemek amacıyla tüm biyokimyasal belirteçlerin bir arada değerlendirilmesi ve bu verilerin korelasyonunun incelenmesi amaçlanmıștır. Böylece orak hücreli hastaların osteoporoz riskinin takibinde biyokimyasal belirteçleri öne çıkarmak hedeflenmiştir.

\section{GEREÇ VE YONTEM}

Çalıșma prospektif randomize olarak orak hücre anemili olan 18 yas üzeri hastalarda gerçekleștirildi. Çalıșma grubu olarak genetik analizi homozigot HbSS olan Hatay Mustafa Kemal Üniversite Hastanesi Dahiliye Hematoloji departmanında takipli 18 yaș ve üzerindeki 33 hasta olgu alındı. Kontrol grubu olarak da benzer yaș ve cinsiyette 34 sağlıklı birey çalıșmaya dahil edildi. Gebe ve emziren kadınlar ile ek kronik hastalığı olan kișiler çalıșma dıșı bırakıldı. Her iki grup çalışma hakkında bilgilendirilerek aydınlatılmış onam form onayları alındıktan sonra olgulardan $5 \mathrm{~mL}$ kan numunesi alındı. Çalıșmamızda mevsimsel değişim göz önünde bulundurularak sağlıklı ve hasta bireylerin örnekleri yaz mevsiminde toplandı ve ölçüm aşamasında seri analizler mümkün olduğunca aynı saatlere denk gelecek şekilde gerçekleştirildi.

Kan örnekleri; Biyokimya tüplerine alındı ve $4^{\circ} \mathrm{C}$ 'de 1500 xg'de 15 dakika santrifüje edildi ve analiz gününe kadar $-80^{\circ} \mathrm{C}$ derin dondurucuda saklandı. Laboratuvar analizi sırasında derin dondurucuda muhafaza edilen kan serum örnekleri oda sıcaklığına getirilerek P1NP, P1CP, BALP, OC, DPD, PYD, HYP ve CTX serum düzeyleri ELISA yöntemi ile spektrofotometrik (Thermo Scientific/MultiscanGo UV) olarak 450 nm'de analiz edildi. Elde edilen kemik döngüsü belirteç düzey verileri her iki grup arasında karșılaștırıldı. Ek olarak 25(OH)D seviyeleri spektrofotometrik yöntem ile ticari kit kullanılarak (Siemens Advia Centaur Xp) ölçüldü.

Serum P1NP (PC) Elisa Kit Katalog no: 201-12-1351, P1CP (PC) Elisa Kit Katalog numarası 201-12-1374, BALP (PC) Elisa Kit Katalog no 201-12-1494, OC (PC) Elisa Kit Katalog numaraSI 201-12-1556, DPD (PC) Elisa Kit Katalog numarası 201-121524, PYD (PC) Elisa Kit Katalog numarası 201-12-1909, HYP (PC) Elisa Kit Katalog numarası 201-12-1901, CTX (PC) Elisa Kit Katalog numarası 201-12-1350, Elisa immünoassay kitleri ile yapılan analizler üreticilerin protokolleri takip edilerek gerçekleștirildi Kullanılan Elisa kitlerinin tamamı SunRed Biotechnology Company Shanghai markalıdır.

\section{İstatistik Analizi}

Shaphiro wilk testi ile verilerin normal dağılıma uygunluğu belirlendi. Normal dağılıma sahip değișkenlerin iki bağımsız grupta karșılaștırılmasında Student-t testi, normal dağılıma uygun olmayanlarda ise Mann Whitney U testi kullanıldı. Sayısal değișkenler Spearman korelasyon katsayısı ile test edildi. Tanımlayıcı ölçülerde sayısal değişkenler için ortalama \pm standart sapma, istatistikleri kullanıldı. İstatistiksel analizler için SPSS 21.0 kullanıldı ve $p<0,05$ istatistiksel olarak anlamlı kabul edildi. 


\section{BULGULAR}

Çalıșmamıza katılan yașları 18-48 arasında değișen 33 orak hücre anemili hastanın yaş ortalaması $29.94 \pm 8$ idi. Grupların yaș dağılımı ortalaması Tablo 1'de gösterilmiștir. Hasta ve kontrol grubu yaş ortalamaları birbirinden farklı değildi ( $p=0.564)$.

OHA hastalarından olușan çalıșma grubu OC düzeyleri

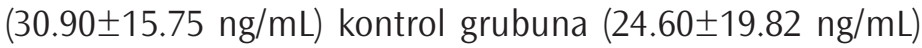
kıyasla anlamlı derecede yüksek bulundu $(p=0.016)$. PINP, PICP, BALP düzeyleri çalıșma ve kontrol grubunda istatistiksel olarak anlamlı değișiklik bulunmadı. (sırası ile, $p=0.345$ 0.071-0.607) (Tablo 1).

Osteoporoz yıkım markerleri olan CTX, HYP ve PYD düzeylerine bakıldığında gruplar arasında istatistiksel olarak anlamlı farklılık gözlenmemiștir. (CTX, $p=0.763$; HYP, $p=0.546$; PYD, $p=0.890)$ (Tablo 1).

Grupların 25(OH)D düzey karșılaștırmasında ise hasta grubunun ( $14.37 \pm 6.24 \mathrm{ng} / \mathrm{mL}) 25(\mathrm{OH}) \mathrm{D}$ düzeyleri kontrol gurubuna $(22.88 \pm 6.62 \mathrm{ng} / \mathrm{mL})$ kıyasla anlamlı derecede düşük bulundu ( $p=0.001$ ) (Tablo 1).

Tablo 1: Tüm değişkenlerin gruplara göre kıyası

\begin{tabular}{|c|c|c|c|c|c|}
\hline & \multicolumn{2}{|c|}{ Kontrol (n=34) } & \multicolumn{2}{c|}{ Hasta (n=33) } & \\
\hline Değișkenler & Ort \pm SS & 0rtanca & 0rt \pm SS & Ortanca & p \\
\hline Yaș & $31.6 \pm 7.82$ & 32.5 & $29.94 \pm 8$ & 29 & 0.564 \\
\hline PINP (ng/mL) & $352.90 \pm 297.27$ & 309.73 & $247.60 \pm 189.47$ & 170 & $0.345^{* *}$ \\
\hline PICP (ng/mL) & $341.56 \pm 254.71$ & 242.33 & $406.50 \pm 246.11$ & 330.38 & $0.071^{* *}$ \\
\hline BALP (U/L) & $141.75 \pm 96,4$ & 103.46 & $116.50 \pm 60.81$ & 91.62 & $0.607^{* *}$ \\
\hline OC (ng/mL) & $24.60 \pm 19.82$ & 16.58 & $30.90 \pm 15.75$ & 27.01 & $0.016^{* *}$ \\
\hline CTX (ng/mL) & $18.24 \pm 11.45$ & 17.29 & $20.28 \pm 13.39$ & 15.54 & $0.763^{* *}$ \\
\hline HYP (nmol/mL) & $24.61 \pm 17.35$ & 19.21 & $25.46 \pm 15.40$ & 20.78 & $0.546^{* *}$ \\
\hline PYD (ng/mL) & $51.67 \pm 30.62$ & 43.53 & $5265 \pm 24.76$ & 45.82 & $0.890^{*}$ \\
\hline Vit_D (ng/mL) & $22.88 \pm 6.62$ & 21.6 & $14.37 \pm 6.24$ & 13.28 & $0.001^{* *}$ \\
\hline * Student-t Test, ** Mann Whitney U test & & & \\
\hline
\end{tabular}

Korelasyon çizelgesi orak hücre hasta grubu örnekleminde parametreler arasındaki ilișkiyi, bu ilişkinin gücünü ve yönünü göstermektedir. Veriler normal dağılıma uymadığı için Spearman Rank korelasyon katsayıları uygulanmıștır Korelasyon katsayısı negatif ise değișkenlerden biri artarken diğeri azalmakta anlamına gelirken, pozitif korelasyon değișkenlerden biri artarken diğerinin de attığını gösterir. Sonuç olarak Tablo 2'te görüldügüü gibi orak hücre anemili hastalarda 25(OH)D hariç tüm parametrelerin birbirleri ile yüksek pozitif korelasyon gösterdikleri görülmüștür.

\section{TARTISTMA}

Çalıșmamızda, OHA'lı hastalar ve sağlıklı bireylerden alınan kan örneklerinde osteoporoz ile ilișkili biyokimyasal belirteçlerin analizleri değerlendirildi. Bu bağlamda, kemik döngüsü yapım belirteçleri olan PINP, PICP, BALP, OC ve kemik döngüsü yıkım belirteçleri; CTX, PYD ve HYP serum düzeyleri analiz edilerek, hasta ve kontrol bireylerin sonuçları birbirleri ile karşılaştırıldı. Ayrıca hasta ve kontrol grubunda Vitamin D düzeylerine bakılarak osteoporoz ihtimali değerlendirildi.

OHA'nın patofizyolojisini olușturan en temel durum olan vazo-oklisif krizlerin anlaşılabilmesi için çok sayıda çalıșma bulunmaktadır, fakat bugün hala OHA'nın kemik mineral yoğunluğuna (KMY) etkisi yeterince aydınlatılabilmiş değildir (10-12). KMY'nin, osteoporoz ve kırık riskini tanımladığı düşünülmektedir. Radyolojik bir yöntem olan Dual Enerji X Ișını Absorbsiyometrisi (DEXA) osteoporoz tanısında altın standarttır fakat osteoporozun daha geç safhalarında bulgu vermekte ve sık aralıklarla kullanıldığında insan sağlığı açısından sakıncaları bulunmaktadır (13). Halbuki ilk defa doktora bașvuran bir hastanın kemik kayıp hızı hakkında biyokimyasal kemik döngü belirteçleri daha yararlı olabilmektedir. Osteoporozun kemik döngü belirteçleri ile erken dönemde tanınabildiğini savunan kaynaklar literatürde mevcuttur (14-16). Uluslararası Osteoporoz Vakfı (IOF) ve Uluslararası Klinik Kimya ve Laboratuvar Tıbbı Federasyonu (IFCC) klinik çalıșmalarda kullanılmak üzere kemik döngü belirteçlerinden yapım ve yıkım için PINP ve CTX'i referans analit olarak kullanmayı önermektedir. Ayrıca yapılan çalıșmalarda kemik döngü belirteçlerinin osteoporoz tedavisine yanıt hakkında da farmakodinamik bilgi sağladığını ve hastada tedavinin izlenmesi için yaygın olarak kullanıldığı bildirilmiștir (14).

Yetișkin kadın ve erkekleri dahil ettiğimiz çalışmamızda kontrol grubu yaș ortalaması $(31.6 \pm 7.82,18-47)$ ile hasta grubu yaș ortalaması $(29.94 \pm 8,18-48)$ arasında önemli bir fark bulunmamaktadır ( $p=0.564$ ) (Tablo 1). Kadınlarda büyüme evresinin sonu ve iskelet konsolidasyonu sonrasında, genellikle 35 yașlarında kemik döngü belirteçlerinin seviyeleri azalmakta fakat menopoz geçiș döneminde yeniden ve hızla artmaktadır. Menopoz sonrası dönemde kemik döngü belirteçlerinin yüksek seviyelerde kalması beklenir $(17,18)$. Karıșıklık yaratabilecek parametreyi ekarte edebilmek için, menapoz yaşına ulaşmamış deneklerin seçilmesine özen gösterildi.

Azinge ve Bolarin tarafından yapılan orak hücre anemisini içeren bir çalıșmada, 20 hasta ve 20 sağlıklı bireyde OC ve BALP kemik döngü göstergesi olarak değerlendirilmiștir. Serum BALP çalışma grubunda kontrol grubuna göre daha yüksek bulunmuștur $(p<0.05)$. Serum OC, kontrol grubu ile anlamlı bir fark göstermemiștir (19). Sonuçlarımıza göre, hasta ve kontrol grubunda BALP konsantrasyonunda istatistik- 
sel olarak anlamlı bir fark bulunmamıștır $(p=0.607)$. Ayrıca verilerimiz Azinge ve Bolarin'in çalıșmasından farklı olarak OC'nin hasta grubunda anlamlı șekilde arttığını belirtmekte$\operatorname{dir}(p<0.005)$.

Gaziantep Üniversitesi'nde yapılan bașka bir araștırmada talasemi majör hasta grubunda yapım belirteci olarak BALP ve OC, yıkım belirteci olarak pridinyum çapraz bağları (PYD ve DPD) değerlendirilmiștir. Belirtilen sonuçlara göre BALP ve OC parametreleri gruplar arasında anlamlı bir değișiklik göstermezken, PYD hasta grubunda önemli ölçüde yüksek bulunmuștur (20). Bu çalıșmanın verileri, aksine OC'nin hasta grubunda anlamlı șekilde arttığını göstermektedir $(p<0.005)$. Ayrıca gruplarımız arasındaki PYD seviyelerinde anlamlı bir fark gözlenmemiștir. ( $p=0.109)$ (Tablo 1).

Çalıșmamızda kullanılan diğer bir parametre olan D vitamini eksikliği başlı başına önemli bir küresel sağlık sorunudur. D vitamini kalsiyumun normal emilimi ve kalsiyum homeostazını korumak için gereklidir (21). OHA'li hastalarda da D vitamini eksikliği oldukça yaygındır ve hasta popülasyonunun \%96'sı bu eksiklik ile savaşmaktadır. Adewoye ve ark. tarafından yapılan ve 14 OHA'li yetişkin bireyin dahil edildiği bir çalışmada yapım belirteci olarak OC, yıkım belirteci olarak CTX ve $25(\mathrm{OH})$ D ölçülmüștür. Tedavi öncesi tüm hastalarda ortalama $25(\mathrm{OH})$ D seviyesi $10.7 \pm 4.7 \mathrm{ng} / \mathrm{mL}$ olarak düșük bulunmuștur. Ayrıca yüksek CTX $(0.87 \pm 0.5 \mathrm{ng} / \mathrm{mL})$ ve $\mathrm{OC}$ seviyeleri (12.3 $\pm 3.7 \mathrm{ng} / \mathrm{mL}$ ) gözlenmiștir. Tedaviden sonra tüm hastaların $25(\mathrm{OH})$ D seviyeleri (38.8 $\pm 13.9 \mathrm{ng} / \mathrm{mL}$ ) $(p<0.001)$ CTX, OC seviyelerinin düzeldiği kaydedilmiștir (22). Çalışmamızda hasta grubunda kontrol grubuna kıyasla düşük D vitamini ve yüksek serum OC düzeyi ile Adowoye çalışmasını destekler niteliktedir. Ancak CTX parametresi için gruplar arasında herhangi bir fark bulunmamıștır (Tablo 2).

Tablo 2: Hasta grubundaki değişkenlerin korelasyon katsayıları

\begin{tabular}{|c|c|c|c|c|c|c|c|}
\hline Değișkenler & PICP & BALP & OC & CTX & HYP & PYD & $25($ OH)D \\
\hline PINP & $0.835^{* *}$ & $0.631^{* *}$ & $0.727^{* *}$ & $0.664^{* *}$ & $0.716^{* *}$ & $0.582^{* *}$ & 0.164 \\
\hline PICP & & $0.661^{* *}$ & $0.599^{* *}$ & $0.669^{* *}$ & $0.763^{* *}$ & $0.684^{* *}$ & 0.071 \\
\hline BALP & & & $0.552^{* *}$ & $0.707^{* *}$ & $0.641^{* *}$ & $0.598^{* *}$ & -0.117 \\
\hline OC & & & & $0.673^{* *}$ & $0.660^{* *}$ & $0.620^{* *}$ & 0.124 \\
\hline CTX & & & & & $0.688^{* *}$ & $0.583^{* *}$ & 0.137 \\
\hline HYP & & & & & & $0.642^{* *}$ & 0.011 \\
\hline PYD & & & & & & & -0.302 \\
\hline
\end{tabular}

$* * * 0.05<p<0.001$

Cabral ve ark. tarafından yapılan bir literatür tarama sonuçlarına göre en çok atıf yapılan belirteçlerin kemik rezorpsiyonu, kemik dinamikleri ile en yüksek korelasyonu gösteren CTX olduğunu ve kemik olușumunu gözlemlemek için en çok tercih edilen markerin BALP olduğunu belirtmekte ve ayrıca bu iki parametre arasında gözlemlenen yüksek korelasyona ișaret etmektedir (23). Bu çalıșmada da osteoporoz ile ilișkili yapım ve yıkım biyobelirteçleri birlikte değerlendirilmiștir. Orak hücreli hastalarımızın kemik yapım / yıkım belirteçleri Tablo 2'de korelasyon analizi ile belirtilmiștir $(n=29)$. Kemik yapım belirteci olarak BALP ve kemik yıkım belirteci olarak CTX çalıșmamıza dahil edilmiș ve aralarında Cabral ve arkadaşlarının çalıșmalarını destekleyen pozitif korelasyon saptanmıştır. ( $r=0.707$ ) Ayrıca yapılan tüm bu literatür taramalarında PINP ve HYP belirteçlerinin orak hücrede çalıșıldığı herhangi bir kaynağa rastlanmamıștır. Çalıșmamızın bu yönü ile literatüre katkı sağladığını düșünmekteyiz.

\section{SONUC}

Kemik yapım belirteci olan OC'nin hasta grubunda yüksek olması ( $p=0.016$ ), osteblastik aktivitenin arttığına işaret eder ve orak hücre hastalarında kemik döngüsünün artmıș olduğunu düşündürebilir.

İstatistiksel olarak anlamlı bulunmasa da hasta grubundaki yıkım marker (CTX, PYD, DPD, HYP) konsantrasyonları kontrol grubuna kıyasla yüksek ölçülmüştür. Osteblastik aktiviteyi destekleyecek osteoklastik aktivitenin yeni başladığını ve ölçüm için anlamlı orana ulaşmadığını düşünmek yanlış olmayacaktır.

Sonuç olarak farklı yayınlarda değişik markerler yüksek bulunsa da tüm çalıșmalarda belirtildiği üzere kemik döngü biyokimyasal parametreler OHA'lı hastalarda göz ardı edilmemelidir. Ancak analizlerin duyarlılığı ve özgüllügüu, daha büyük bir örneklem büyüklügü ile daha fazla araștırılmalıdır.

Kısıtlığımız ise, bütçe yetersizliği nedeniyle DEXA gibi radyolojik tetkikler kullanılamamış, sadece biyokimyasal belirteçlerin kemik olușum ve rezorbsiyonun göstergesi olarak kemik hastalıklarının tanısında nerede yer aldıkları araştırılmıştır.

\section{BILDIRIMLER}

Bu makale birinci yazarın "Orak Hücre Anemili Hastalarda Osteoporoz IIle Ilișkili Yeni Biyokimyasal Markerlerin Tanıdaki Yeri” bașlıklı ve 2019 tarihli yüksek lisans tezinin yeniden düzenlenmesi ile olușturulmuştur.

Değerlendirme

Dıș danıșmanlarca değerlendirilmiștir.

Çıkar Çatıșması

Yazarlar bu makale ile ilgili herhangi bir çıkar çatıșması bildirmemișlerdir.

Finansal Destek

Bu makale 16797 nolu proje olarak Hatay Mustafa Kemal Üniversitesi Bilimsel Araștırma Projeleri Koordinatörlügü tarafından desteklenmiştir.

Etik Beyan

Bu çalıșma için Hatay Mustafa Kemal Üniversitesi Tıp Fakültesi Girișimsel Klinik Araștırmalar Etik Kurulundan 09/02/2017 tarih ve 49 sayılı karar ile izin alınmış olup Hel- 
sinki Bildirgesi kriterleri göz önünde bulundurulmuștur.

\section{KAYNAKLAR}

1. Mandal AK, Mitra A, Das R. Sickle Cell Hemoglobin. Subcell Biochem. 2020;94:297-322. DOI:https://doi.org/ 10.1007/9783-030-41769-7_12

2. Pinto VM, Balocco M, Quintino S, Forni GL. Sickle cell disease: a review for the internist. Intern Emerg Med. 2019;14(7):105164. https://doi.org/ 10.1007/s11739-019-02160-x

3. Aguilar C, Vichinsky E, Neumayr L. Bone and joint disease in sickle cell disease. Hematol Oncol Clin North Am. 2005;19(5):929-41, viii. https://doi.org/ 10.1016/j. hoc.2005.07.001

4. Rees DC, Williams TN, Gladwin MT. Sickle-cell disease. Lancet. 2010;376(9757):2018-31. https://doi.org/ 10.1016/S01406736(10)61029-X

5. Kim HK, Kim MG, Leem KH. Osteogenic activity of collagen peptide via ERK/MAPK pathway mediated boosting of collagen synthesis and its therapeutic efficacy in osteoporotic bone by back-scattered electron imaging and microarchitecture analysis. Molecules. 2013;18(12):15474-89.

6. GuillerminetF, Beaupied H, Fabien-SouléV, Tomé D, Benhamou $\mathrm{CL}$, Roux $\mathrm{C}$, et al. Hydrolyzed collagen improves bone metabolism and biomechanical parameters in ovariectomized mice: an in vitro and in vivo study. Bone. 2010;46(3):827-34. https://doi.org/ 10.1016/j.bone.2009.10.035

7. da Silva Junior GB, Daher EeF, da Rocha FA. Osteoarticular involvement in sickle cell disease. Rev Bras Hematol Hemoter. 2012;34(2):156-64. https://doi.org/ 10.5581/15168484.20120036

8. Nolan VG, Nottage KA, Cole EW, Hankins JS, Gurney JG. Prevalence of vitamin D deficiency in sickle cell disease: a systematic review. PLoS One. 2015;10(3):e0119908. https:// doi.org/10.1371/journal.pone.0119908

9. Garrido C, Cela E, Beléndez C, Mata C, Huerta J. Status of vitamin D in children with sickle cell disease living in Madrid, Spain. Eur J Pediatr. 2012;171(12):1793-8. https://doi.org/ 10.1007/s00431-012-1817-2

10. Nelson DA, Rizvi S, Bhattacharyya T, Ortega J, Lachant N, Swerdlow P. Trabecular and integral bone density in adults with sickle cell disease. J Clin Densitom. 2003;6(2):125-9. https://doi.org/ 10.1385/jcd:6:2:125

11. Miller RG, Segal JB, Ashar BH, Leung S, Ahmed S, Siddique $S$, et al. High prevalence and correlates of low bone mineral density in young adults with sickle cell disease. Am J Hematol. 2006;81(4):236-41. https://doi.org/ 10.1002/ajh.20541

12. Lal A, Fung EB, Pakbaz Z, Hackney-Stephens E, Vichinsky EP. Bone mineral density in children with sickle cell anemia. Pediatr Blood Cancer. 2006;47(7):901-6. https://doi.org/ 10.1002/pbc.20681
13. Feingold KR, Anawalt B, Boyce A, Chrousos G, de Herder WW, Dhatariya K, et al. Endotext. 2000.

14. Vasikaran S, Eastell R, Bruyère 0 , Foldes AJ, Garnero P, Griesmacher A, et al. Markers of bone turnover for the prediction of fracture risk and monitoring of osteoporosis treatment: a need for international reference standards. Osteoporos Int. 2011;22(2):391-420. https://doi.org/ 10.1007/ s00198-010-1501-1

15. Lorentzon M, Branco J, Brandi ML, Bruyère O, Chapurlat R, Cooper C, et al. Algorithm for the Use of Biochemical Markers of Bone Turnover in the Diagnosis, Assessment and Follow-Up of Treatment for Osteoporosis. Adv Ther. 2019;36(10):2811-24 . https://doi.org/ 10.1007/s12325-019-01063-9

16. Henriksen K, Christiansen C, Karsdal MA. Role of biochemical markers in the management of osteoporosis. Climacteric. 2015;18 Suppl 2:10-8. https://doi.org/ 10.3109/13697137.2015.1101256

17. Eastell R, Garnero P, Audebert C, Cahall DL. Reference intervals of bone turnover markers in healthy premenopausal women: results from a cross-sectional European study. Bone. 2012;50(5):1141-7. https://doi.org/ 10.1016/j. bone.2012.02.003

18. Guañabens N, Filella X, Monegal A, Gómez-Vaquero C, Bonet $\mathrm{M}$, Buquet $\mathrm{D}$, et al. Reference intervals for bone turnover markers in Spanish premenopausal women. Clin Chem Lab Med. 2016;54(2):293-303. https://doi.org/ 10.1515/cclm-20150162

19. Azinge EC, Bolarin DM. Osteocalcin and bone-specific alkaline phosphatase in sickle cell haemoglobinopathies. Niger J Physiol Sci. 2006;21(1-2):21-5. https://doi.org/ 10.4314/njps. v21i1-2.53934

20. Eren E, Yilmaz N. Biochemical markers of bone turnover and bone mineral density in patients with beta-thalassaemia major. Int J Clin Pract. 2005;59(1):46-51. https://doi.org/ 10.1111/j.1742-1241.2005.00358.x

21. Kaza PL, Moulton T. Severe vitamin D deficiency in a patient with sickle cell disease: a case study with literature review. J Pediatr Hematol Oncol. 2014;36(4):293-6. https://doi.org/ 10.1097/MPH.0000000000000045

22. Adewoye AH, Chen TC, Ma Q, McMahon L, Mathieu J, Malabanan A, et al. Sickle cell bone disease: response to vitamin D and calcium. Am J Hematol. 2008;83(4):271-4. https://doi.org/ 10.1002/ajh.21085

23. Cabral HW, Andolphi BF, Ferreira BV, Alves DC, Morelato RL, Chambo A, et al. The use of biomarkers in clinical osteoporosis. Rev Assoc Med Bras (1992). 2016;62(4):368-76. https://doi.org/ 10.1590/1806-9282.62.04.368 